\title{
Boots on the streets: a "policization" of the armed forces as the new normal?
}

DOI 10.2478/jms-2019-0003

Received September 14, 2018; accepted August 20, 2019

\begin{abstract}
The article analyses how the boundaries of postmodern military organizations are changing and how these evolutions affect their relations with the civilian society. The case of the Belgian Defence and the deployment of its military personnel in the streets are used as a case study to illustrate this transformation. Since January 2015, in response to the imminent terrorist threat in Belgium, military units have been deployed in support of the police to monitor sensitive areas, guard buildings and patrol the streets. The article analyses, first, how the population reacted to these new "proximity" roles and, second, the impact of these homeland deployments on the expeditionary readiness of the Belgian Defence and its capacity to carry out its primary missions.

The empirical analyses are, based on several quantitative and qualitative surveys, carried out among the Belgian population and the personnel of the Belgian Defence. In particular, the impact of the evolution of the public's support over time on the blurring of the traditional roles of the military and the use of the military for internal security tasks is analysed.
\end{abstract}

Keywords: Military organizations, police, homeland operations, and public opinion

\section{Blurring of boundaries between military and police organizations}

The rise of the Western nation-states at the beginning of the 19th century led to a strict functional differentiation between the agencies responsible for their external

\footnotetext{
*Corresponding authors: Delphine Resteigne, Head of the Chair of Sociology at the Royal Military Academy in Brussels and Associate Professor at the University of Mons, Belgium. E-mail: Delphine.resteigne@mil.be; Philippe Manigart, Former Professor of Sociology and Head of the Department of Behavioral Sciences of the Belgian Royal Military Academy in Brussels, E-mail: Philippe.manigart@gmail.com
}

and internal security, that is, the military and the police (Tilly 1992). While the mission of the mass armed forces from the 19th to mid-20th centuries was to prepare and conduct wars in the service of the nation-states (for defending their borders or invading other states), police forces were charged with law and order within the borders of these nation-states. At the end of the 20th century, however, this clear division of labour began to blur. As Keegan (2001: 39) observed, we went, in some ways, back to a situation that existed in Europe in the Middle Ages:

War is escaping from state control, into the hands of bandits and anarchists (...) Therefore the great work of disarming tribes, sects, warlords and criminals - a principal achievement of monarchs in the 17th century and empires in the 19th - threatens to need doing all over again.

One of the reasons was the radical restructuring of Western armed forces under the impact of four macrostructural variables such as the economic environment (globalization), the technology (big data revolution), the social-cultural context (increased cultural diversity) and the geopolitical context (the end of the Cold War). The old mass armed forces and the forces-in-being of the Cold War have been replaced by postmodern military organizations to use a common terminology in the sociology of the military organizations (Boëne 2018; Manigart 2018; Moskos and Burk 1994; Moskos et al. 2000). As this article will try to show, given their extremely diverse missions, Western postmodern armed forces have ceased being organizations specialized in the management of collective, organized violence (war); they have become constabulary forces specialized in crisis management, both inside and outside the national borders.

The aim of this article is to analyse how the boundaries of postmodern military organizations are changing and how these evolutions impact their relations with the civilian society. The case of the Belgian Defence and the deployment of its military personnel in the streets is used as a case study to illustrate this transformation. Since January 2015, in response to the imminent terrorist threat in Belgium, military units have been deployed in support of the police to monitor sensitive areas, guard 
buildings and patrol the streets. The article is divided into two parts. The first part sketches the radical restructuring process undergone by the military organizations of Western postindustrial societies since the end of the 1990s and shows how it has, among other things, led to a blurring of the borders between postmodern military organizations and the police. The second part analyses how the Belgian population reacted to these new "proximity" roles and the impact of these homeland deployments on the expeditionary readiness of the Belgian Defence and its capacity to carry out its primary missions. As we will see, despite greater visibility and the support of the public opinion, military personnel are not really in favour of keep on doing those tasks which are not considered as their "normal" job. The empirical analyses are based on several quantitative and qualitative surveys carried out among the Belgian population and the personnel of the Belgian Defence. In particular, the impact of the evolution of the public's support over time on the blurring of the traditional roles of the military and the use of the military for internal security tasks is analysed.

\section{Macrostructural causes of the evolution}

From the 19th to mid-20th centuries, in the West European nation states, the boundaries between the military and the police were rather well delineated. It should be noted here that no such clear division of labour existed in the colonial territories of these states. For instance, in the Belgian Congo, one had the so-called Force Publique, a mixed organization, part army and part police, that fought against the German Army in Africa during World War I but was also and mainly used for internal control. There was a clear division of labour between the two organizations: while the military was responsible for the external security of the nation, the police maintained the internal order (Easton and Moelker 2010: 11). This was in part because military organizations at the time were "unique" organizations (Boëne 1990). First, these organizations were almost exclusively composed of people in uniform; second, the structural (hierarchy) and functional differentiation (tasks specialization) in these armies was extremely simple: there were few hierarchical levels and within each hierarchical stratum, specialization was minimal (Harries-Jenkins 1973; Janowitz 1971; Van Doorn 1975). Most soldiers carried out similar and specifically military tasks (i.e. combat functions). To use Durkheim's (2004) terminology, the division of labour in these organizations was extremely low, and consequently, the type of solidarity that existed between the members of these strata was mechanical. Therefore, if mass armed forces were relatively homogeneous organizations, they were also very different from and had relatively few interactions with civilian society; the military institution was what Goffman (1961) called a total institution, that is, an isolated, enclosed social system whose primary purpose is to control most aspects of its participants' lives. Defining what was military was at the time easy: a soldier/sailor was a fighter, a specialist in legitimate organized (external) violence (Biderman 1967). In reality, in many countries, like Belgium, the separation was less clear-cut, as a result of the existence of the Gendarmerie, an internal police force that, formally, was part of the armed forces, but with a special status.

But after World War II, under the impact of the technological and social-cultural evolution that transformed Western industrial societies, military organizations became more structurally and functionally heterogeneous. One of the consequences of this greater heterogeneity was that the civilian-military border progressively became fuzzier and more porous. At the present time, a member of a defence organization is no longer synonymous with a fighter. First, only a minority of military personnel is still engaged in combat functions (less than 20\% compared to more than $90 \%$ in the 19th century); there has been a shift from combat functions towards support, technical and administrative functions, that is, functions that are not fundamentally different from similar functions in the civilian sector. To cite one example, during the Civil War, combat functions accounted for $93.2 \%$ of the occupational specializations in the U.S. Army, while in 1954, only $28.8 \%$ of Army enlisted personnel were still engaged in purely military occupations (Janowitz and Little 1974: 47). In 1982, in the Belgian armed forces, the percentage of combat functions was $24.2 \%$ (24.8\% in the Army, $22.6 \%$ in the Air Force and $19.2 \%$ in the Navy) (Manigart 1985: 79). Second, people in uniform are no longer the only members of military organizations; there has been a significant increase of civilians. Third, given that most of the personnel inside, these organizations are carrying out different roles, and their interests are no longer the same; this greater diversity and heterogeneity have, therefore, led to a less strong (organic) solidarity among the members of the organization (Manigart and Resteigne 2013).

On the international stage, the new geostrategic environment that emerged at the end of the Cold War can be characterized as one of greater complexities and uncertainties compared to the certainties of the bipolar world of the previous decades (Freedman 1991). One has gone from a war environment dominated by a binary logic 
"friend/foe" to an environment of crisis response operations based on a fuzzy logic "friend/foe/non-foe" (Battistelli et al. 1999: 1).

Till the end of the Cold War, the enemies of Western armed forces were well-identified (there were other military organizations), and the rules of engagement (ROE) were clear and straightforward (winning the country's wars or deter the adversary). In contrast, in the 21st century, the missions of the armed forces of postindustrial Western societies have radically changed. There is no single, overarching mission anymore, but instead a very large variety of missions. Certainly, a conventional war has not become totally impossible or unimaginable (consider Russia and its annexation of Crimea, its shadow war in eastern Ukraine and its cyberattacks in the Baltic states); territorial defence even remains in the ultimate justification of national armed forces. But, for countries like Belgium, in the short and middle term, it is probably not the most likely scenario. Traditional interstate wars have, to a great extent, been supplanted by intra-state wars that cut across state boundaries (Van Creveld 1991). Ethnic/ religious/sectarian identity-based conflicts (such as in Ukraine, Libya, Syria, Iraq, Mali, Congo, etc.) and terrorist threats (such as the one posed by the Islamic State) have become the typical examples of postmodern conflicts. Kaldor (1999) called these new types of conflicts as "new wars" as these are distinguished from the "old wars".

The new wars involve a blurring of the distinctions between war (usually defined as violence between states or organized political groups for political motives), organized crime (violence undertaken by privately organized groups for private purposes, usually financial gain) and large-scale violations of human rights (violence undertaken by states or politically organized groups against individuals" (Kaldor 1999: 2).

In short, the main missions (in terms of frequency at least) of postmodern military organizations are to counter these types of threats and to maintain and restore order in regions where our interests are in jeopardy and/or for humanitarian or ethical reasons. As Janowitz (1971) long ago predicted, Western military organizations have become constabulary forces. According to his definition,

The military becomes a constabulary force when it is continuously prepared to act, committed to the minimum use of force, and seeks viable international relations, rather than victory, because it has incorporated a protective military posture (...) The constabulary concept encompasses the entire range of military power and organization. At the upper end are the weapons of mass destruction; those of flexible and specialized capacity are at the lower end, including the specialists in military aid programs, in para-military operations, in guerilla and counterguerilla warfare. (Janowitz 1971: 418).
Concretely, at the present time, these new constabulary missions range from conventional war fighting, counter-insurgency, maintaining or enforcing peace in unstable regions of the world to fighting international terrorism abroad - and more recently at home - and other threats. Postmodern armed forces have become organizations specialized in crisis management in a broader sense. One of the implications of the development of a constabulary posture is, as Easton and Moelker (2010: 21) underline, that

The military thus has to be able to vary and fluctuate the intensity of its use of force. This requires competences to escalate and de-escalate in the application of force within a short period of time, and within short intervals. A constabulary force also needs the ability to deal with a range of different environments and specific security scenarios.

As important as the diverse nature of the postmodern armed forces' missions is the fact that fighting these new threats is not a monopoly of national military organizations anymore; there are other specialized actors working with or alongside the military, such as other national contingents, local militias, police units, NGOs, the media, and so on. This, in turn, implies a high degree of international as well as, more recently, national collaboration.

In other words, what one sees is the same evolution as in the private sector, that is, the proliferation of joint ventures, strategic alliances, ad hoc groups and virtual organizations. According to Schuler and Jackson (1996), a virtual organization is a temporary network of companies with diverse core competencies that quickly form a collaboration to take advantage of fleeting opportunities. Having exploited these opportunities, the "corporation" may disband as swiftly as it formed (Schuler and Jackson 1996: 44). International operations, such as the EU Training Mission in Mali (EUTM), Operation Desert Falcon in Iraq and Operation Vigilant Guardian (OVG) at home in Belgium, are examples of these virtual organizations in the security domain. One important implication is that it requires the development of some sort of "cultural interoperability", that is, the development of a common organizational culture encouraging the effective cooperation among different organizational cultures (Resteigne 2012).

\section{Towards organizational mimicry?}

If inter-organizational cooperation between Western military organizations is not new (intensive permanent cooperation began after World War II with the establishment of the NATO alliance and intensified after 9/11 with the multiplication of crisis response operations abroad), 
cooperation between internal security actors is however much more recent, particularly in Belgium. Mostly, it was one of the results of the rise of international terrorism after $9 / 11$. Nowadays, the distinction between internal and external security has become fuzzy, as numerous organizations are involved, both abroad and at home, in the fight against these new, more diffuse and multifaceted threats. To again take the example of the fight against the Islamic State, where is the boundary between external and internal security, as Belgian F-16s were recently flying from a Jordanian airfield to strike terrorist targets both inside Iraq and Syria and Belgian Special Forces are training and mentoring Iraqi units while Belgian soldiers patrol the streets of Belgian cities to protect the population against a possible terrorist attack?

The respective roles and tasks of the military and the police are also less well-defined than in the past. On the one hand, as part of their constabulary missions abroad, soldiers are trained in public order management and have become specialists in crowd control, patrolling, and so on, as their colleagues are from the police; they are now applying these new skills at home. On the other hand, as part of their anti-terror mission, police special units have developed military skills and are now more heavily weaponized; police forces are also now being used abroad (in Afghanistan, Kosovo, etc.) in the fight against terror, drug trafficking, and so on. In short, there is an increasing convergence between military and police organizations in their respective missions, skills and training. Campbell and Campbell (2010) have referred to a process of organizational mimicry between the two organizations to describe the tendency to imitate the strategies, structures and procedures of other organizations engaged in the same type of work. Contrary to the early 20th century, there is currently a strong influence for convergence between the two organizations (Table 1).

During the late 20th century, both organizations were confronted with particular social pressures and three "wicked" problems at the macro-level (Campbell and Campbell 2010: 15-16): the internationalization of organized drug crime; the proliferation of terrorist groups and a geopolitical fragmentation of formerly integrated societies. Those changes have thus rendered the distinctions between domestic and foreign policy less evident. These convergences between military and police roles can, however, become problematic and, sometimes, dysfunctional for democratic societies as a close connection between the police and the military is often a formula for anti-democratic political leanings and authoritarian government (Campbell and Campbell 2010: 3).

Besides those macro evolutions, we can also notice some evolutions at the institutional level. The professionalization of the armed forces and of the police has not simplified the current working tasks. Mimetic and normative processes have increased the operational interactions between the two institutions, notably by shared training experiences or by intervening in common joint task forces (like the Belgian First Aid and Support Teams in Belgium which are rapid reaction units enabling emergency aid teams to be sent out to countries hit by a natural or manmade disaster. It is a cross-departmental unit, spanning the Prime Minister's office, Federal Public Services Foreign Affairs, External Trade and Development Cooperation, Public Health \& Environment, Home Affairs and Budget, as well as the Ministry of Defence). Coercive processes, in terms of cultural expectations, have also pushed both institutions together. As public opinion surveys show (see later), citizens' representations regarding the role of

Tab. 1: Environmental and institutional components of organizational mimicry. (adapted from Campbell and Campbell 2010: 8)

\begin{tabular}{ll}
\hline Macro-changes: environmental components & Contemporary period \\
\hline Political attitudes & Fighting terrorism; nation building \\
Economic pressures & Global drug crime; geopolitical fragmentation \\
Social/demographics & Global terrorism; ethnic conflicts \\
Legal considerations & Joint cooperation; joint mission \\
Assessment & Strong pressure police/military duties convergence \\
Meso-changes: institutional Components & \\
Mimetic components & Common goals; unclear paths \\
Normative components & Shared members; shared procedures; shared resources \\
Coercive components & Demands for action; legal mandates; contractor efforts \\
Assessment & Strong influence for convergence \\
Micro-changes: individual components & \\
Individual attitudes & Norms and values (individualist, looking for meaningful work and self-consideration, mobile) \\
Assessment & Resistance against role convergence \\
\hline
\end{tabular}


the Belgian Defence and its tasks tend to reinforce this convergence with the police. These coercive pressures are also reinforced by the political pressures and the need to avoid any duplication of means in the name of a search for a greater functionality of both services.

Consequently, at the micro level, with the growing "constabularization of the military", current soldiers do have to develop new competencies in both fighting and policing... two tasks very different in terms of cognition, tasks and leadership style. There is also a strong resistance towards this kind of "mission creep". The military was not designed to exert these constabulary tasks, and the expectations of the personnel still do not fit with those new roles. Although both the police and the military are Janusian (Soeters et al. 2003) "uniformed organizations" (Soeters 2000), both still differ and have their own procedures and culture. A Janusian organization (from the two faces of the Roman god Janus) is an organization with two sides: the hot side (the soldier in the battlefield) and the cold side (the one in garrison) (Soeters et al. 2003: 238). The concept was originally developed by McCormick (1998). This can create coordination problems when they are forced to operate together on the home front, as is the case for Belgian military and police personnel when they patrol the streets. To take just one element, the military remains - although a lot less than in the past - a very hierarchical and centralized organization (especially infantry units) while the police has a flatter hierarchy and is used to work on a more decentralized way in the field, with more autonomy given to the men and women in the streets.

As previously mentioned, in Belgium, the use of the military in the fight against terrorism at home is more recent than in other Western countries (such as the United Kingdom, France and the United States) that have been confronted with terrorism for many more years. It began in January 2015 when the government decided to deploy military personnel in the streets of Brussels and Antwerp. It was the beginning of OVG which is still underway 4 years after the first deployment. After the terrorist attacks in Paris on 13 November 2015, the number of protected cities was increased as well as the number of deployed soldiers. In March 2016, Operation Spring Guardian (OSG) was added specifically to support the police in securing nuclear installations.

These two operations (OVG and OSG) fall under the last of the six strategic missions of the Belgian Defence. Strategic Mission 6 consists of contributing within the national borders to the security of the Belgian society, on the basis of the exclusivity of expertise or military capabilities, or where civilian resources are inadequate. The joint doctrine of the Belgian Defence further distinguishes between 10 possible engagement scenarios of the Belgian armed forces. Homeland Operations fall under the last of these 10 scenarios. These operations are intended to provide emergency assistance irrespective of the origin of the emergency (natural disaster, industrial accident and hostile intent,) and to take part in the fight against all forms of crimes (including terrorism) that can cause damage to society in the broadest sense or put the rule of law at risk. In the case of anti-terrorism operations, armed forces can only be used in support of the police and in the context of a probable terrorist threat (level 3 or 4). Under OVG and Operation Spring Guardian, military personnel carry out two types of missions: patrols or fixed stations. Street patrols provide protection to all users of the public space. As for fixed stations as buildings, they are considered as sensitive places. In this case, the aim is to provide protection to those working in these places.

The first deployment of troops in January 2015 consisted of 150 persons. But the number rapidly increased to more than 1800 persons in October 2016 to decrease slightly at the beginning of 2017. According to internal data from the Defence Ministry, in December 2018, despite the fact that the threat level had been decreased to level 2, the homeland operation was still by far the most important one: on a total 1107 soldiers in operations, 478 were deployed in Belgium; it was significantly less than in 2016, when there were 2192 deployed soldiers in the context of OVG and OSC: 896 in the streets and 1296 in support and standby. One major change was also the deployment of reservists in the streets since 2018, in accordance with the new concept of the operational reserve, also a new example of blurring boundaries between here, military and civilian roles.

Given that, for the military, homeland anti-terrorist operations are rather recent, that, in the context of these new missions, military personnel have now to work together with - and under the supervision of - policemen/women and that the culture of these two uniformed organizations and their ROE are different, an important question arises: what is the opinion of the Belgian population concerning this new role of the Belgian Defence? In a democracy indeed, it is the citizens who decide whether or not specific roles, certain kinds of missions and operations are legitimate. In other words, the support of public opinion is an important variable given that, to cite Dalton (1988: 21), the public's view generally defines the acceptable bounds of politics, within which political elites can resolve the remaining controversies. Although elite manoeuvre room is probably greater in the defence domain than in other political domains (Rokkan 1960; Manigart 1986), defence policy in recent years has been 
increasingly shaped by the pressures of the mass media and of public opinion (Shaw 1991: 184-190).

In the next section, we therefore analyse the opinion of the Belgian population and the personnel of the Belgian Defence concerning this new type of missions and, as far as military personnel are concerned, what they think about collaborating with the police and how they live this cooperation in the field.

\section{Opinions on homeland operations}

The data on the public's views collected from various surveys conducted in 2015 (La Libre/Radio Télévision Belge Francophone (RTBF)/Dedicated), 2016 (Grand Baromètre RTL/IPSOS/Le Soir), and in 2016-2018 (Eurobarometers 86, 87, and 89) among representative samples of the Belgian population. We also used the online survey conducted by Listen (2017) in May 2017 for the Belgian Defence among a representative sample of 1000 Belgians.

The data regarding the personnel of the Belgian Defence were gathered in 2015, at the beginning of operation OVG. Two internal surveys were carried out by the Department of Behavioral Sciences of the Royal Military Academy. The first one, in March 2015, at the request of the Defence Minister, surveyed (online) a representative sample (quota method) of 1397 military and civilian members of the Belgian Defence (Lecoq 2015). The aim was to replicate a previous survey on the identity of the Belgian Defence conducted in 2009. The second one was conducted (also online) in the context of a Master thesis at the Royal Military Academy in November-December 2015.
In this case, the sample was not representative at all of the whole population of the Belgian Defense; rather, it was composed of only 313 French-speaking respondents from 3 infantry units (1-3 Lanciers, 12-13 de Ligne, Commando Training Center) having participated in 2015 to OVG (Born 2016). Table 2 lists these surveys and their main characteristics.

\subsection{Opinion of the Belgian population}

As seen in the preceding section, the current geopolitical environment is radically different from the bipolar one of the Cold War; but perhaps more important than the changing objective risk situation is the subjective dimension, that is., the perception that the public has of the new threats, and more particularly of the terrorist one. For several years now, the Eurobarometer (EB) surveys ask Europeans what is their opinion about the two most important issues facing their country that are at the moment out of a list of 15 items. According to the Fall 2016 standard wave (EB 86), after the terrorist attacks in Paris in 2015 and in Brussels on March 2016, one-third of the Belgian respondents (33\%) thought that terrorism became the most important of the 15 proposed issues, followed by immigration (27\%). The last time it had happened was in Fall 2001 after the attacks in New York and Washington on 9/11 (EB 56). In Fall 2016, the percentage was down 10 points (23\%), but it was still number 2 . In the Spring 2018 Eurobarometer (EB 89), it had further fallen 10 percentage points (13\%).

In the Eurobarometer 87 (Spring 2017), respondents were asked about possible actions which could be taken at the European level: beside other major challenges, Belgians were still primarily worried about terrorism. In that

Tab. 2: List of the surveys.

\begin{tabular}{|c|c|c|c|c|c|}
\hline Survey & Commissioned by & Date & Sample size & Method & Representative \\
\hline \multicolumn{6}{|l|}{ Belgian public opinion surveys } \\
\hline Dedicated & La Libre/RTBF & December 2015 & 2811 & Online & Yes \\
\hline Eurobarometer 86 & European Commission & November 2016 & 1022 & CAPI & Yes \\
\hline Eurobarometer 87 & European Commission & May 2017 & 1025 & CAPI & Yes \\
\hline Eurobarometer 89 & European Commission & March 2018 & 1028 & CAPI & Yes \\
\hline IPSOS & Le Soir/RTL & September 2016 & 2881 & Online & Yes \\
\hline Ivox/Royal Military Academy & Belgian Defence & December 2013 & 1000 & Online & Yes \\
\hline Listen & Belgian Defence & May 2017 & 1000 & Online & Yes \\
\hline \multicolumn{6}{|c|}{ Surveys among the personnel of the Belgian Defence } \\
\hline Royal Military Academy & Belgian Defence & December 2013 & 1397 & Online & Yes (Mil \& Civ) \\
\hline Royal Military Academy & Belgian Defence & March 2015 & 1397 & Online & Yes (Mil \& Civ) \\
\hline Royal Military Academy & Royal Military Academy & Nov/Dec 2015 & 313 & Online & No (Army only) \\
\hline
\end{tabular}


survey, they thought that specific measures should be taken at the European level for fighting terrorism (82\%), for solving the migration question $(76 \%)$, in the domain of security and defence (75\%) and for the protection of the external borders (74\%).

In this context, it is then quite understandable that Belgians tend to support OVG. From a survey conducted by Dedicated for La Libre and RTBF in December 2015 among a representative sample of the Belgian population 18 years and older, $72 \%$ of the respondents supported the deployment of military personnel in the streets (21\% were without any opinion, so only $7 \%$ of the respondents were against such a deployment). Almost a year later, in September 2016, a similar survey carried out by IPSOS for RTL TVI and Le Soir showed that the support of the public opinion was slightly lower but still very strong: $65 \%$ of the respondents thought that the presence of soldiers in the streets should be maintained. Approval was largely shared between regions (69\% in Wallonia, 64\% in Brussels and 65\% in Flanders) and political preferences.

From the survey conducted by Listen in May 2017 among a representative sample of Belgians, we see in
Table 3 that the major fear shared by the Belgian population was international terrorism (61\%), far above organized crime (38\%) and ethnic conflicts in Europe (36\%).

If we now look at the support given by Belgians to the missions executed by the Belgian Defence (Table 4), we see that military support to the police in the streets came first (78\%). Among those $78 \%$, more than one in two (54\%) "fully" supported it. In comparison, F-16 missions abroad received the "full support" of only $42 \%$ of the Belgian population. From these data, one can conclude that, at the time at least, OVG was considered by Belgian respondents as the most important mission for the Belgian Defence.

\subsection{Opinion of the personnel of the Belgian Defence}

One saw that if in the past the threat of an enemy invasion was a real possibility against which countries had to defend themselves, the current situation is radically different. The post-Cold War period has been characterized

Tab. 3: Major fears (2017).

\begin{tabular}{|c|c|c|c|}
\hline & $\%$ of "rather agree" & \% of "without any opinion" & $\%$ of "rather disagree" \\
\hline International terrorism & 61 & 23 & 16 \\
\hline Organized crime & 38 & 31 & 31 \\
\hline Ethnic conflicts in Europe & 36 & 31 & 33 \\
\hline Accident on a nuclear site & 34 & 29 & 36 \\
\hline Worldwide war & 34 & 27 & 39 \\
\hline Dispersion of nuclear, biological and chemical weapons & 33 & 30 & 38 \\
\hline The (accidental) launch of a nuclear missile & 27 & 22 & 51 \\
\hline Epidemics & 25 & 30 & 45 \\
\hline Nuclear conflict in Europe & 24 & 22 & 54 \\
\hline Conventional war in Europe & 22 & 25 & 53 \\
\hline
\end{tabular}

Source: Listen voor Defensie, Een onderzoek bij de Belgische bevolking tussen 17 en 65 jaar, mei 2017.

Tab. 4: Support to the missions executed by the Belgian Defence (2017).

\begin{tabular}{|c|c|c|}
\hline & $\%$ of "fully or rather support" & \% of "do not know" \\
\hline Military support to the police in the streets & 78 & 9 \\
\hline F-16 missions abroad & 66 & 17 \\
\hline Training and education to foreign military personnel & 67 & 19 \\
\hline Military support to the police for securing nuclear sites & 64 & 20 \\
\hline Military support to prison guards on strike & 62 & 15 \\
\hline Anti-piracy & 60 & 23 \\
\hline $\begin{array}{l}\text { Military support to foreign governments for reforming their security sector } \\
\text { (including the military) }\end{array}$ & 58 & 22 \\
\hline
\end{tabular}

Source: Listen voor Defensie, Een onderzoek bij de Belgische bevolking tussen 17 en 65 jaar, mei 2017. 
by the fact that the threat has become less direct, fuzzier. More importantly, current missions are more diverse, going from conventional war to humanitarian missions, counterterrorism abroad and antiterrorism at home. Given this broader range of missions, the question of the legitimate roles of national armed forces arises. What should the roles of the Belgian Defence be according to the Belgian public? This was the subject of a question asked in an online survey carried out among a representative sample of military and civilian members of the Belgian Defence in March 2015, that is, after the January 2015 terrorist attacks in Paris against Charlie Hebdo and a Hypercacher supermarket at the Porte de Vincennes and after an anti-terrorist raid in Verviers (Belgium). Respondents were first asked whether, for them, various action domains were part of the missions of the Belgian Defence. Then, 8 of the 19 proposed domains concerned homeland missions. Table 5 shows the results.

As one can see, the three most cited missions were traditional ones: defending the Belgian territory (98\% of the respondents thought this was role for the Belgian Defence), contributing to stability, peace and security (98\%) and participating to military operations in Europe (97\%). In fourth place came a traditional internal task of the Belgian Defence, that is, helping the country in case of disasters.

Tab. 5: Roles of the Belgian Defense (2015).

\begin{tabular}{lc}
\hline & \% of “yes" \\
\hline Defending the Belgian territory & 98 \\
Contributing to stability, peace and security & 98 \\
Participating in military operations in Europe & 97 \\
Providing help in case of disasters in the country & 96 \\
Defending the territory of the member states of NATO & 95 \\
and the EU & \\
Contributing to the fight against international terrorism & 95 \\
Contributing to the peace process, if necessary through & 89 \\
the use of force & \\
Military action outside Europe WITH UN agreement & 88 \\
Providing free services to the Belgian population & 88 \\
Guaranteeing/symbolizing national unity & 86 \\
Offering help in case of disasters abroad & 80 \\
Monitoring public places in Belgium & 77 \\
Contributing to the fight against radicalism in Belgium & 66 \\
Helping to counter cyberattacks & 65 \\
Contributing to the fight against illegal immigration & 56 \\
Serving the foreign policy of Belgium & 53 \\
Helping young people to integrate into society & 54 \\
Contributing to the fight against drug trafficking & 52 \\
Military action outside Europe WITHOUT UN agreement & 39 \\
\hline
\end{tabular}

Source: Royal Military Academy 2015 (Lecoq 2015).
It is interesting to note that, according to another survey carried out in December 2013 by the Department of Behavioral Sciences of the Royal Military Academy for the Belgian Defence Minister among a representative sample of the Belgian population, this traditional non-military task was the most cited by the public (92\%), before the two more traditional military missions, defending the country (91\%) and contributing to stability (87\%) (Lecoq 2014). Among the public, the fourth most cited mission was the fight against international terrorism (83\%). Among the personnel of the Belgian Defence, this new mission came in sixth position (95\%).

Among the other non-traditional military roles supported by a large majority of the personnel of the Belgian Defence in 2015, one found first providing free services to the Belgian population: almost 9 in 10 respondents (88\%) thought that was a mission for the armed forces. More interesting for this article was the fact that $77 \%$ and $66 \%$ of the respondents respectively agreed that monitoring public places in Belgium and contributing to the fight against radicalism in Belgium were part of the missions of the Belgian Defence.

The remaining roles received less agreement: contributing to the fight against illegal immigration (56\%), helping young people to integrate into society, for example by teaching them a trade (54\%) and contributing to the fight against drug traffic (52\%).

Three other questions in this same survey dealt with homeland operations. One measured the support for various ongoing missions of the Belgian Defence in the world and in Belgium. Among these missions was the new monitoring mission in support of the federal police. This operation was largely approved (83\%). More than 9 out of 10 respondents (91\%) thought that the Belgian Defence should conduct missions abroad as well as at home. But when the armed forces do homeland operations, for more than 8 out of 10 respondents, this should be in partnership with one or several other civilian organizations and not alone: $38 \%$ said that it should be in support of the police and $42 \%$ in support of other organizations (such as the civil protection, the firemen or the customs).

For the personnel of the Belgian Defence, homeland missions should essentially consist of monitoring $(84 \%)$ or antiterrorism $(83 \%)$ operations. Nearly 7 out of 10 respondents $(69 \%)$ also believed that the military should patrol the streets, as is the case in France with the Sentinelle operation (and as they are presently doing in Belgium).

We now turn to the way French-speaking soldiers having participated in 2015 to the first rotations of OVG lived their deployment and their collaboration with the 
federal Police. Before analysing some of the items, it is important to again stress the fact that the survey was conducted only among three French-speaking infantry units. The results are therefore only indicative and not necessarily representative of the population of soldiers deployed in 2015 and even less of those who rotated after. One should also remind readers that it was realized before the terrorist attacks in Brussels on 22 March 2016, that is, before the full and permanent deployment of soldiers in the streets. It is likely that had the survey been carried out now, 4 years after the first deployment of troops under OVG, the results would probably be different. The fact that many soldiers have already done multiple rotations and that the mission has, in a sense, become routine constitutes indeed a greater burden for the personnel as well as for the units concerned (mainly infantry units). Therefore, it is likely that the initial enthusiasm has diminished or even disappeared.

As shown in Table 6, during the first year of OVG, almost all the respondents (98\%) said that they were rather or very motivated to carry out homeland missions. Half of them (52\%) even felt that they were more useful in this type of mission than when they were deployed abroad. Almost all of them (94\%) again rather or very much agreed that to be deployed in Belgium had professionally motivated them and that it was also a personally rewarding experience.

As mentioned earlier, in Belgium, military personnel can only be deployed inside the country for anti-terrorism missions in support and under the control of the police; they cannot operate alone. It means that soldiers in the field are working alongside colleagues from the police and under their supervision, while when abroad doing the same kind of job (monitoring, patrolling the streets, controlling crowds, etc.), they are alone and follow their own ROE. OVG was therefore quite different as an operation

Tab. 6: Opinions of soldiers on homeland missions (2015).

\begin{tabular}{lc}
\hline & \% “rather or strongly agree" \\
\hline $\begin{array}{l}\text { I feel motivated to carry out this type } \\
\text { of mission because it is to defend my } \\
\text { country }\end{array}$ & 98 \\
Being deployed in Belgium motivates \\
me professionally \\
$\begin{array}{l}\text { Being deployed in Belgium is a } \\
\text { personally rewarding experience } \\
\text { I consider myself more useful in } \\
\text { this type of mission than when I am } \\
\text { deployed abroad }\end{array}$ \\
\hline
\end{tabular}

Source: Royal Military Academy 2015 (Born 2016). than what they were trained and used to do. How did the first deployed soldiers adapt to this new situation and how were their relations with their colleagues of the police? Ten items in the survey tried to shed some light on these aspects (Table 7).

Soldiers directly implicated in OVG appeared to be more supportive of this kind of mission than the military and civilian employees of the Belgian Defence in general: $93 \%$ of the former said that they rather or very much supported the monitoring mission in support of the federal police against $77 \%$ of the latter (however, this difference could be - and more than probably is - partly because that the survey among the personnel of the Belgian Defence was carried before the November Paris attacks while the second survey was done just after).

As far as the participation of the military in antiterrorist homeland operations is concerned, more than two-thirds (68\%) of the respondents largely agreed that they should be conducted in support of the police. Not only were the respondents supportive of working with the police, they were even more numerous (79\%) to say that they should cooperate more often and in other kinds of missions, like crowd control (what they are trained to do and do, but until 2015 exclusively abroad); almost 7 out of $10(68 \%)$ were favourable to the creation of a joint anti-terrorism brigade.

According to the first participants to OVG, the experience of working with the police was quite positive (87\%). This positive assessment was probably partly due to their acknowledgement that the police has more expertise in this domain than themselves: $71 \%$ said that they rather or very much agreed that "working with police officers is necessary, we are in an environment they know better". The experience of working with the police was so positive for most of the soldiers $(75 \%)$ that they were looking forward to working again with the police in the future, whether for training or exercises. A fourth of the respondents (24\%) were even ready to leave the Belgian Defence in order to join the police.

This perfectly illustrates another dimension of the blurred boundaries between the military and the police: the smoother and easier transition of people from one organization to the other than in the military organizations of the past. Such transfers, essentially from the military to the police, have become easier than in the past, especially with the December 2015 decision of the Belgian government to create a new Security Corps of 1660 full-time equivalents within the Interior Ministry, the Directorate Surveillance and Protection of the Federal Police. A quota of maximum 150 military personnel is allowed per year. This new Corps, staffed by personnel 
Tab. 7: Opinions of soldiers on their relations with the police (2015).

\% "rather or strongly agree"

I support the monitoring mission in support of the federal police

When the armed forces are conducting missions on the national territory this should be in support of the

police

Collaborating with the police should more frequent, especially in case of demonstrations

The police and the armed forces should unite and create a joint anti-terrorism brigade specialized in this type

Working with police officers is necessary, we are in an environment they know better 71

In the future, I would like to work again with the police whether for training or exercises 75

Working with the police motivates me to leave the Belgian Defence to work for the police 24

I feel respected by my colleagues in the police 88

I trust the policemen/women who work with me as much as my military colleagues 32

The police is as professional as my unit

We are better prepared than the police for this type of mission

34

Collaborating with the police is difficult because of the different ways of carrying out the work 36

The information we receive is the same as that received by the police

from the police and ex-soldiers, will be tasked with many of the roles the military is currently doing (but as far as the Belgian Defence is concerned, only in an emergency situation, level 3 of the threat), that is, the protection of infrastructure (NATO, EU, embassies, etc.), airports, nuclear sites, courts, and so on.

The last six items dealt with the perception of respondents towards their colleagues from the police. Here the results were more mixed. If the great majority of soldiers ( $88 \%$ ) felt they were respected by their colleagues from the police, this did not necessarily translate in really trusting them: only one in three (32\%) said that they trusted the policemen/women who worked with them as much as their military colleagues. This is naturally quite understandable given the fact that their contacts with the police are episodic and most often short-term (given the rotation of the day to day missions, they do not work permanently with the same persons), but, in emergency situations, such a lack of trust could prove problematic. The soldiers who answered the survey also thought that police personnel were not as professional as they were (only 34\% said that the police was as professional as their units); in fact, three-fourths thought that they were better prepared for this type of mission than the police. In a way, it illustrates the difficulties inherent to this new form of collaboration: it is likely that had one have questioned the policemen/women, they would probably have said the same thing as the soldiers, that is, that they were better prepared than the military for this type of mission. Each one thinks his/her way of doing things is better than the other. Traditionally, this was a typical task of the police, but with the multiplication of crisis response operations, it also became a task for which the Army is trained. The difficulties of working together were also apparent in the answers to the last two items: around one-third of the respondents rather or very much agreed that collaborating with the police was difficult because of the different ways of carrying out the work (36\%) and that the information they receive is the same as that received by the police (33\%).

Since the first survey conducted in 2015, it appears, however, from various sources (unions, personal interviews with officers, etc.) that military personnel have become less positive towards OVG. Among others, the very static nature of the mission is criticized by many Belgian soldiers. Even if the patrols have been adapted, the fatigue and the nature of the tasks do not fit with a lot of soldier's expectations. Even the Chief of Defence, General Marc Compernol, in an interview in the weekly Télémoustique (22 February, 2017) was very critical about that kind of mission and mentioned that

[s]oldiers reassure the public (...). Personally, I find that this is not the role of the Defense. The internal security of a country is a problem for the police. The Defense can of course come in support in moments of extreme threat. But we must not do this ad vitam aeternam. We must, however, obey the government. Unless the threat level goes down, we will stay on the streets.

However, even with a lower threat level (level 2 in 2019), the Government has decided to maintain around 500 military personnel in the streets. This decision is probably not a good thing for the morale of some soldiers who have now been deployed at home for more than 3 years. These homeland missions are, for some, very 
difficult to accept for their families who do not understand why they have to stay for 5 weeks at a base located only few kilometres away from home! Because of the nature of the job and the negative impact on their family, many are thinking of quitting the Army, many of them for the police. This is particularly alarming because human resources remain one of the main challenges of the Belgian Defence nowadays. The majority of military personnel is indeed above 40 years old. According to data from the Directorate General Human Resources, in 2017, the number of new applicants decreased by one-fifth, partly because the newly introduced short-term contracts allow recruits up to 26 years old maximum instead of 34 years old previously.

\section{Conclusion}

The current postmodern Western defence organizations have more open, porous borders than the mass armies of the 19th and early 20th centuries. In particular, the roles of today's armed forces are not solely combat roles anymore; they have become much more diverse (going from fighting conventional wars to conducting crisis response operations both abroad and in the homeland). Postmodern military organizations, especially on their hot side (the operations), have become virtual organizations: they almost always carry out their constabulary-type missions in close cooperation with other organizations, military or not.

Since January 2015, in response to the imminent terrorist threat in Belgium, military units have been deployed in support of the police to monitor sensitive areas, guard buildings and patrol the streets. For the Belgian Army, this was a new mission, although, since the end of the Cold War, it had been used for similar kinds of work and postures abroad as part of their crisis response operations, first in the Balkans in the 1990s (and more particularly in Kosovo) and more recently in Afghanistan. The personnel had therefore already been trained for constabulary-type of missions and had acquired the necessary basic skills. One could even say that, given the less kinetic character of the Belgian contribution to crisis response operations abroad, the switch to homeland police-like operations has probably been easier for Belgian soldiers than for their American colleagues (given that the U.S. Army still remains a predominantly war-fighting organization). So, in a sense, it is probably not so surprising that, according to the surveys carried out at the beginning of OVG, military personnel seemed to largely accept their new homeland missions and were more than willing to work with and in support of the police. They even thought that what they did in Belgium was more useful than what they used to do (and still do) when they are deployed abroad, because here, in a very direct way, they contribute to defend their country.

What was initially foreseen to be a temporary measure has become permanent, in part because of the support of public opinion towards that kind of missions. So, with the time, the initial motivation and enthusiasm among soldiers has begun to alter. A lot of recruits had signed up for taking part in operations abroad and for adventure, not for playing security guards in the streets of Brussels. Consequently, as it was underlined by General Marc Thys, the commander of Belgium's land forces, a lot of people quit the organization because of the operation. Also important at the organizational level, these kinds of homeland deployments compromise the operational readiness of the Belgian Defence and its capacity to carry out its primary missions (participating to crisis response operations abroad). In other words, the continuous deployment of a significant part of the operational units in homeland operations is detrimental to the preparedness of these units for combat missions and not sustainable in the long term, given that they do not have the necessary time anymore to train. This is also the case in other major military power like France who has also cut back training to free up troops and deploy up to 10,000 armed troops on the streets. One of the complaints of military commanders is indeed that their units are presently overstretched and, at the end, will not be able to exert more kinetic actions. Structural solutions, such as the announced creation of a specialized new security corps within the federal police, will be necessary.

Finally, should the use of the military for homeland operations become more frequent, it would be advisable to develop new and more flexible ROE (for instance, by making it possible in specific circumstances for military personnel to act alone and not necessarily under the supervision of the police).

The blurring process between the military and the police is thus ongoing but, at the organizational as well as at the individual level, the negative impact is huge both in terms of training and morale. Despite societal visibility and the public's support, major internal resistances among the military personnel remain against these new tasks and this convergence process. In other words, what one could call the policization of the armed forces will most likely not become soon accepted as the new normal. 


\section{References}

Battistelli, F., Amendola, T., \& Galantino, M. G. (1999). The fuzzy environment and postmodern soldiers: The motivations of the Italian contingent in Bosnia. In: Paper presented at the Biennial International Conference of the Inter-University Seminar on Armed Forces and Society, Baltimore, October 22-24.

Biderman, A. D. (1967). What is military? In: Tax, S. (ed.), The Draft: A Handbook of Facts and Alternatives. The University of Chicago Press, Chicago, pp. 122-137.

Boëne, B. (1990). How 'unique' should the military be? A review of representative literature $\&$ outline of a synthetic formulation. European Journal of Sociology/Archives Européennes de Sociologie, 31, pp. 3-59.

Boëne, B. (2018). The military as a tribe among tribes. Post-modern militaries and civil-military relations. An update. In: Caforio, G., \& Nuciari, M. (eds.), Handbook of the Sociology of the Military, 2nd edn. Springer International Publishing, New York, pp. 179-202.

Born, T. (2016). Perceptions de l'utilisation des militaires dans les rues: Leçons de l'année 2015. Master thesis, Royal Military Academy, Chair of Sociology, Brussels.

Campbell, D., \& Campbell, K. (2010). Soldiers as police officers/ Police officers as soldiers: Role evolution and revolution in the United States. Armed Forces and Society, 36, pp. 327-350.

Dalton, R. J. (1988). Citizen Politics in Western Democracies: Public Opinion and Political Parties in the United States, Great Britain, West Germany and France. Chatham House Publishers, Chatham.

Durkheim, E. (2004 [1893]). De la division du travail social. Paris: PUF.

Easton, M., \& Moelker, R. (2010). Police and military: Two worlds apart? Current challenges in the process of constabularisation of the armed forces and militarisation of the civilian police. In: Easton, M., Den Boer, M., Janssens, J., Moelker, R., \& Vander Beken, T. (eds.), Blurring Military and Police Roles. Eleven International Publishing, Den Haag, pp. 14-41.

Freedman, L. (1991). The Gulf war and the new world order. Survival, 33, pp. 195-209.

Goffman, E. (1961). Asylums: Essays on the Social Situation of Mental Patients and Other Inmates. Anchor Books, New York.

Harries-Jenkins, G. (1973). From conscription to volunteer armies. Adelphi Paper No. 103.

Janowitz, M. (1971). The Professional Soldier: A Social and Political Portrait (with a New Prologue). Free Press, Glencoe.

Janowitz, M., \& Little, R. D. (1974). Sociology and the Military Establishment, 3rd edn. Sage, Beverly Hills.

Kaldor, M. (1999). New and Old Wars: Organized Violence in a Global Era. Stanford University Press, Stanford.
Keegan, J. (2001). The threat from Europe. Spectator (pp. 38-39), March 24.

Lecoq, V. (2014). Image de la Défense belge. Royal Military Academy, Department of Behavioral Sciences, Brussels, Technical Report.

Lecoq, V. (2015). Identité de la Défense belge: enquête 2015. Royal Military Academy, Department of Behavioral Sciences, Brussels, Technical Report.

Listen voor Defensie. (2017). Een onderzoek bij de Belgische bevolking tussen 17 en 65 jaar, Technical Report.

Manigart, P. (1985). Les forces armées belges en transition: une analyse sociologique. Editions de l'Institut de Sociologie, Brussels.

Manigart, P. (1986). The Belgian defense policy domain in the 1980s. Armed Forces and Society, 13, pp. 39-56.

Manigart, P. (2018). Restructuring the armed forces. In: Caforio, G., \& Nuciari, M. (eds.), Handbook of the Sociology of the Military, 2nd edn. Springer International Publishing, New York, pp. 407-425.

Manigart, P., \& Resteigne, D. (2013). Sortir du rang: la gestion de la diversité à la Défense belge. L'Académie en poche, Brussels.

McCormick, D. (1998). The Downsized Warrior: America's Army in Transition. New York University Press, New York.

Moskos, C. C., \& Burk, J. (1994). The postmodern military. In: Burk, J. (ed.), The Military in New Times: Adapting Armed Forces to a Turbulent World. Westview Press, Boulder, pp. 141-162.

Moskos, C. C., Williams, J. A., \& Segal, D. R. (2000). The Postmodern Military: Armed Forces after the Cold War. Oxford University Press, Oxford.

Resteigne, D. (2012). Le militaire en opérations multinationales. Regards croisés en Afghanistan, en Bosnie, au Liban. Bruylant, Brussels.

Rokkan, S. (1960). Citizen participation in political life. International Social Science Journal, 12(special issue), pp. 7-99.

Schuler, R. S., \& Jackson, S. E. (1996). Human Resource Management: Positioning for the 21st Century. West Publishing Company, Minneapolis.

Shaw, M. (1991). Post Military Society. Polity Press, London.

Soeters, J. (2000). Culture in uniformed organizations. In: Ashkanasy, N. M., Wilderom, C. P. M., \& Peterson, M. F. (eds.), Handbook of Organizational Culture and Climate. Sage Publications, London, pp. 465-481.

Soeters, J., Winslow, D., \& Weibull, A. (2003). Military culture. In: Caforio, G. (ed.), Handbook of the Sociology of the Military. Kluwer Academic, New York, pp. 237-254.

Tilly, C. (1992). Coercion, Capital and European States, AD 990-1990. Blackwell, Cambridge.

Van Creveld, M. (1991). The Transformation of War. Free Press, New York, p. 1991.

Van Doorn, J. (1975). The decline of the mass army in the West: General reflections. Armed Forces and Society, 1(147), p. 158. 